\title{
Synthesis, Spectral, Anti-Liver Cancer and Free Radical Scavenging Activity of New Azabicyclic Thienoyl Hydrazone Derivatives
}

\author{
M. Manimaran1, A. Ganapathi2 ${ }^{*}$, T. Balasankar ${ }^{2}$ \\ ${ }^{1}$ Department of Chemistry, Annamalai University, Annamalai Nagar, India \\ ${ }^{2}$ Chemistry Section, FEAT, Annamalai University, Annamalai Nagar, India \\ Email: ${ }^{*}$ maransuman@gmail.com
}

Received 17 August 2015; accepted 27 September 2015; published 30 September 2015

Copyright (C) 2015 by authors and Scientific Research Publishing Inc.

This work is licensed under the Creative Commons Attribution International License (CC BY).

http://creativecommons.org/licenses/by/4.0/

(c) (i) Open Access

\section{Abstract}

To exploit the potential biological activities of azabicyclic based, seven $2 r$, 4c-diaryl-3-azabicyclo [3.3.1] nonan-9-one-2'-thienoyl hydrazone were synthesized. The structural elucidation and stereochemistry of these compound assigned by FT-IR, ${ }^{1} \mathrm{H},{ }^{13} \mathrm{C}$ and $2 \mathrm{D}$ NMR spectral data. The Structural Activity Relationship (SAR) of the target compounds were examined for their in vitro antiproliferative, antioxidant and antimicrobial activities. The initial screen was treated against human liver cancer cell lines (HepG2) with IC $_{50}$ values determined by MTT assay. Fluoro substitution at para position of phenyl ring compound 12 showed more antiproliferative activity against HepG2 at half maximum inhibitory concentration $\left(\mathrm{IC}_{50}=3.76 \mu \mathrm{g} / \mathrm{mL}\right.$ ) than other target hydrazones. The mechanism of the antitumor action of active compound 12 was investigated through Hoechst stain 33342 analyses. It indicated that the compound inhibited HepG2 cancer cells proliferation by triggering apoptotic cell death. The Free radical scavenging activity of all synthesized compounds were evaluated with $\mathrm{DPPH}^{\bullet}, \mathrm{OH}^{\bullet}$ and $\mathrm{O}_{2}^{--}$radicals. The compounds 11 (IC 50 rang 3.78 - $4.31 \mu \mathrm{g} / \mathrm{mL}$ ) and $15\left(\mathrm{IC}_{50}\right.$ rang $4.61-5.16 \mu \mathrm{g} / \mathrm{mL}$ ) were exhibited higher free radical scavenging activity than standard BHT drug. Besides, all the target compounds were screened for their in vitro antibacterial and antifungal activity against a spectrum of microbial organisms by using twofold dilution method. These studies proved that halogen substituted compounds 12, 13 and 14 were showed excellent inhibitory potency at lowest minimum inhibitory concentration (MIC) range of $6.25-25.5 \mu \mathrm{g} / \mathrm{mL}$. Nevertheless, multiple mechanisms regulating the antioxidant and anticancer effects of the hybrid molecules need to be further investigations.

\section{Keywords}

\section{2-Thienoyl Hydrzones, Antioxidant, Anticancer, Cytotoxicity, Antimicrobial Activity}

\footnotetext{
${ }^{*}$ Corresponding author.
}

How to cite this paper: Manimaran, M., Ganapathi, A. and Balasankar, T. (2015) Synthesis, Spectral, Anti-Liver Cancer and Free Radical Scavenging Activity of New Azabicyclic Thienoyl Hydrazone Derivatives. Open Journal of Medicinal Chemistry, 5, 33-47. http://dx.doi.org/10.4236/ojmc.2015.53004 


\section{Introduction}

At present, human liver cancer is a major reason for death worldwide. The proportion of people suffering from cancer is estimated to continue growing largely because of the aging of population in most countries [1]. Reactive oxygen, nitrogen and sulphur (NOS) are important for an organism's vital activities such as the regulation of biological active compounds. Extreme production of reactive oxygen species causes oxidative stress, chronic diseases and cancer. NOS containing molecules are well known to directly interact with all types of biological molecules, proteins, DNA and lipids [2]-[4]. The shared adverse effects are termed oxidative stress. Oxidative stress has involved in the various hallmark abilities of cancer [2]-[4]. Research over the past numerous decades has established that antioxidants play a protective role in multistage carcinogenesis [3] [4]. Generally, a living organism has protective enzymatic and non-enzymatic antioxidant mechanisms against Reactive Oxygen Species (ROS) induced oxidative damage. Recently, significant attention has focused on identifying synthetic antioxidants that aim several signaling pathways are abnormal in cancer.

The 3-azabicyclo [3.3.1] nonane pharmacophore is present in a wide variety of naturally occurring diterphenoid/nor diterphenoid alkaloids and biological activities [5]-[7]. 2, 4-Diaryl-3-azabicyclo [3.3.1] nonan-9-one derivatives are showed excellent antitumor [8] and antimicrobial [9] activities. Correlation between cytotoxicity and antioxidant capacity of natural/synthetic compounds [10], we are discovered strong cytotoxicity with poor antioxidant properties of synthesized halogen substituted such as $\mathrm{F}, \mathrm{Cl}$ and $\mathrm{Br}$ compounds may be due to the pro-oxidant effects. Although potent antioxidant often possess strong pro-oxidant activity, found low cytotoxicity in synthetic compounds with electron donating functional groups $\left(-\mathrm{CH}_{3},-\mathrm{OCH}_{3}\right.$ and $\left.\mathrm{CH}\left(\mathrm{CH}_{3}\right)_{2}\right)$ present on the aryl rings attached to azabicyclo [3.3.1] nonane-9-ones in line with the observations of Lee et al. [11] Though, multiple mechanisms regulating the antioxidant and cytotoxic effects of the hybrid molecules necessitate to be further investigations.

The half maximum inhibitory concentration $\left(\mathrm{IC}_{50}\right.$ ) has measured the effectiveness of synthesized compounds in inhibiting specific biological functions of anticancer activity and free radical scavenging activity. This quantitative measurement indicates how much of a particular drug is need to inhibit a given biological microorganisms by half. It is generally used as a measure of antagonist drug potency in pharmacological research work. The $\mathrm{IC}_{50}$ values of drug (synthesized target compounds) can be determined by constructing a dose response and investigate the effect of different concentrations of antagonist on reversing agonist activity. IC $_{50}$ values can be measured for a given antagonist by determining the concentration required to inhibit half of the maximum biological response of the agonist. Hepatocellular carcinoma (HepG2) is derived from the liver tissue of human. This cell lines obtained from National centre for cell sciences (NCCS), Pune, India and it is a best suitable cell lines to evaluate the cytotoxicity of synthesized compounds. The use of electron donating and withdrawing substituent at aromatic compounds with regards to biological activity has established [12] and several interesting investigations are made through piperidine based heterocyclic compounds and exhibited antimicrobial, antioxidant, antithrombic, calcium antagonist, hypotensive and neuroleptic activities [13]-[16]. Hydrazone are noteworthy molecule containing extremely reactive azomethyne $(-\mathrm{CONHNC}<)$ are one useful in drug development [17]. 2-Thiophenecarboxylic acid hydrazide has involved significant attention due to the biological activity which has been widely recognized and practically applied in a number of drugs [18] [19].

In this paper, we report synthesis of seven 2r, (Scheme 1) 4c-Diaryl-3-azabicyclo [3.3.1] nonan-9-one-2'thienoyl hydrazones highlights the in vitro antioxidant, antitumor and antimicrobial activities against three kinds of free radicals, human liver hepatocellular carcinoma (HepG2) cell lines, bacteria and fungi strain organisms, respectively.

\section{Experimental Methods}

\subsection{Chemistry}

\subsubsection{Chemicals Equipment Techniques for Structural Elucidation}

2-Thiophenecarboxylic acid hydrazide, substituted aldehydes and solvents were purchased from Sigma-Aldrich ${ }^{\circledR}$, Himedia $^{\circledR}$ and Merck ${ }^{\circledR}$, Germany, were used directly without further recrystellization. Reaction process and purity were monitored by thin layer chromatography (TLC). Physical properties of melting point were determined in an Electro thermal 9100 instrument in open capillaries and are uncorrected. FT-IR analysis has been recorded in an IR-470 SHIMADZU spectrometer (Shimadzu, Tokyo, Japan.) by making pellet of compound with $\mathrm{KBr}$ 

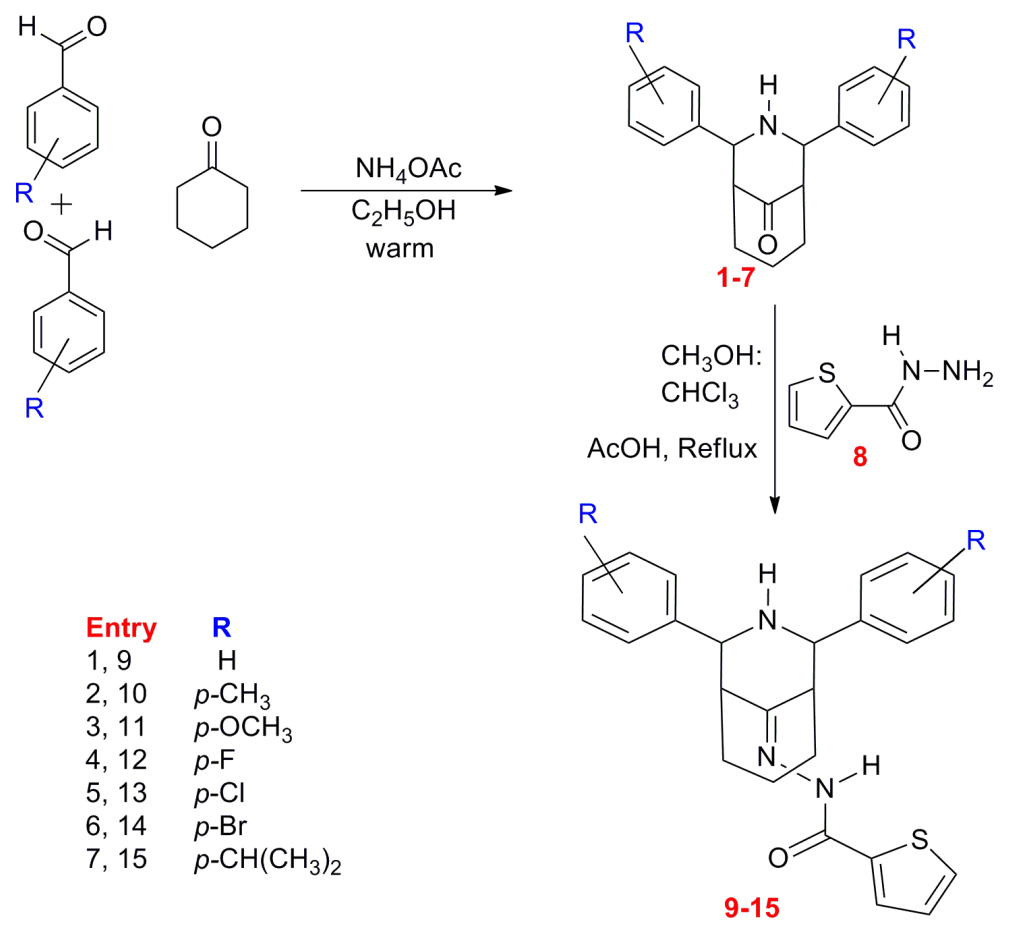

Scheme 1. Synthesis of 2r, 4c-3-azabicyclo [3.3.1] nonan-9-one-2'-thienoyl hydrazones (9-15).

and values are expressed as $v_{\max } \mathrm{cm}^{-1} .{ }^{1} \mathrm{H},{ }^{13} \mathrm{C}$ and 2D NMR spectra were recorded at ambient temperature on a Bruker AMX-400 NMR spectrometer operating at $400.13 \mathrm{MHz}$ for ${ }^{1} \mathrm{H}$ and $100.62 \mathrm{MHz}$ for ${ }^{13} \mathrm{C}$. Chemical shift $(\delta)$ unit expressed in parts per million (ppm) with respect to TMS. Sample was prepared in $\mathrm{CDCl}_{3}$ solvent (10 $\mathrm{mg}$ in $0.5 \mathrm{~mL}$ ). Elemental analysis for all synthesized compounds was performed on an Elementor Vario EL-III CHNS analyzer.

\subsubsection{General Procedure for Synthesized Compound 2r, 4c-Diaryl-3-Azabicyclo [3.3.1] Nonan-9-One-2'-Thienoyl Hydrazones (9-15)}

First 2r, 4c-Diaryl-3-azabicyclo [3.3.1]nonan-9-ones (1-7) were prepared by the condensation of appropriate cyclohexanone (1equiv), respective aromatic aldehyde (2equiv) and Ammonium acetate (1.5equiv) dissolved in ethanol was kept in water bath by maintaining the bath temperature at $60^{\circ} \mathrm{C}-75^{\circ} \mathrm{C}$ with continuous stirring using literature procedure [20]. The crude product precipitated from the solvent was filtered. It was washed through etheric ethanol solution. An ethanol/chloroform/acetone mixture ratio (2:1:1) was used for recrystallization of 1-7 compounds. A mixture of 2r, 4c-Diaryl-3-azabicyclo [3.3.1] nonan-9-one (1 mmol) and 2-Thiophenecarboxylic acid hydrazide $(1.5 \mathrm{mmol})$ was dissolved in methanol and $\mathrm{CHCl}_{3}(1: 1 \mathrm{v} / \mathrm{v})$ and few drops of acetic acid was added as catalyst. The reaction mixture was refluxed for $2-3 \mathrm{~h}$. On the completion of reaction a solid mass was formed. After the precipitate was filtered at room temperature and washed with cold mixture of water/ethanol mixture. The crude compounds were recrystallized from ethanol.

2r, 4c-Diphenyl-3-azabicyclo [3.3.1] nonan-9-one-2'-thienoyl hydrazone 9

IR (KBr) $\left(\mathrm{cm}^{-1}\right)$ : 3034.03, 2924.09, 2854.65 (C-H stretching), 3302.13(-NH-), 1641.42 (C=O stretching), 1510.26 (>C=N stretching), ${ }^{1} \mathrm{H}$ NMR $\left(\mathrm{CDCl}_{3}, \delta \mathrm{ppm}\right): 10.214$ (s, $\left.1 \mathrm{H}, \mathrm{HN}-\mathrm{C}=\mathrm{O}\right), 4.490$ (s, $\left.1 \mathrm{H}, \mathrm{H}-2 \mathrm{a}\right), 4.386$ (s, 1H, H-4a), 3.342 (s, 1H, H-5e), 2.867 (d, 1H, H-7a), 2.76 (s, 1H, H-1e), 1.885 (s, 2H, H-8e, H-6a), 1.590 (m, 3H, $\mathrm{H}-8 \mathrm{a}, \mathrm{H}-6 \mathrm{e}$ and ring NH) 1.417 (s, $1 \mathrm{H}, \mathrm{H}-7 \mathrm{e}), 8.166-7.135$ (m, 13H, aromatic and thienoyl ring protons). ${ }^{13} \mathrm{C}$ NMR ( $\delta \mathrm{ppm})$ : 65.47 (C-2), 63.60 (C-4), 46.09 (C-1), 38.48 (C-5), 28.56 (C-8), 27.34 (C-6), 21.56 (C-7), 142.39 (C-2'), 141.31 (C-4'), 163.56 (C-9), $161.81(\mathrm{HN}-\underline{C}=\mathrm{O}), 141.31$ - 126.35 (aromatic and thienoyl ring carbons).

2r, 4c-Bis (p-methylphenyl)-3-azabicyclo [3.3.1] nonan-9-one-2'-thienoyl hydrazone $\mathbf{1 0}$

IR (KBr) $\left(\mathrm{cm}^{-1}\right)$ : 3041.74, 2956.87, 2922.16 (C-H stretching), $3307.92(-\mathrm{NH}-), 1633.71$ (C=O stretching), 1516.05 (>C=N stretching), ${ }^{1} \mathrm{H}$ NMR $\left(\mathrm{CDCl}_{3}, \delta \mathrm{ppm}\right): 10.005$ (s, $\left.1 \mathrm{H}, \mathrm{HN}-\mathrm{C}=\mathrm{O}\right), 4.476$ (s, $\left.1 \mathrm{H}, \mathrm{H}-2 \mathrm{a}\right), 4.364$ (s, 
1H, H-4a), 3.278 (s, 1H, H-5e), 2.901 (s, 1H, H-7a), 2.751 (s, 1H, H-1e), 1.899 (s, 2H, H-8e, H-6a), 1.663 (m, $3 \mathrm{H}, \mathrm{H}-8 \mathrm{a}, \mathrm{H}-6 \mathrm{e}$ and ring $\mathrm{NH}) 1.442(\mathrm{~s}, 1 \mathrm{H}, \mathrm{H}-7 \mathrm{e}), 2.457\left(\mathrm{~d}, 6 \mathrm{H}, \mathrm{p}-\mathrm{CH}_{3}^{\prime}, \mathrm{CH}_{3}^{\prime \prime}\right.$ are merged together) 8.233 $7.139\left(\mathrm{~m}, 11 \mathrm{H}\right.$, aromatic and thienoyl ring protons). ${ }^{13} \mathrm{C}$ NMR $(\delta \mathrm{ppm}): 65.28(\mathrm{C}-2), 63.44(\mathrm{C}-4) .46 .16(\mathrm{C}-1)$, 38.55 (C-5), 28.56 (C-8), 27.34 (C-6), 21.58 (C-7), 144.66 (C-2'), 140.61 (C-4'), 163.44 (C-9), 162.16 (HN-C =O), 21.18 ( $p-\mathrm{CH}_{3}^{\prime}$ and $\mathrm{CH}_{3}^{\prime \prime}$ are merged together), $139.00-126.34$ (aromatic and thienoyl ring carbons).

2r, 4c-Bis (p-methoxylphenyl)-3-azabicyclo [3.3.1] nonan-9-one-2'-thienoyl hydrazone $\mathbf{1 1}$

IR (KBr) $\left(\mathrm{cm}^{-1}\right)$ : 3032.10, 2926.01, 2845 (C-H stretching), 3302.13 (-NH-), 1639.49 (C=O stretching), 1510.26 (>C=N stretching), ${ }^{1} \mathrm{H}$ NMR $\left(\mathrm{CDCl}_{3}, \delta \mathrm{ppm}\right): 9.933$ (s, $\left.1 \mathrm{H}, \mathrm{HN}-\mathrm{C}=\mathrm{O}\right), 4.447$ (s, $\left.1 \mathrm{H}, \mathrm{H}-2 \mathrm{a}\right), 4.337$ (s, $1 \mathrm{H}$, H-4a), 3.231 (s, 1H, H-5e), 2.885 (bs, 1H, H-7a), 2.716 (s, 1H, H-1e), 1.902 (s, 2H, H-8e, H-6a), 1.774 - 1.567 (m, 3H, H-8a, H-6e and ring $\mathrm{NH}) 1.452(\mathrm{~s}, 1 \mathrm{H}, \mathrm{H}-7 \mathrm{e}), 3.879\left(\mathrm{~s}, 6 \mathrm{H}, \mathrm{p}-\mathrm{OCH}_{3}^{\prime}, \mathrm{OCH}_{3}^{\prime \prime}\right.$ are merged together) 8.229 - 6.990 (m, 11H, aromatic and thienoyl ring protons). ${ }^{13} \mathrm{C}$ NMR ( $\left.\delta \mathrm{ppm}\right): 65.02(\mathrm{C}-2), 63.18(\mathrm{C}-4) .46 .23$ (C-1), 38.62 (C-5), 28.51 (C-8), 27.05 (C-6), 21.60 (C-7), 144.73 (C-2'), 144.40 (C-4'), 163.47 (C-9), 158.97 $(\mathrm{HN}-\underline{\mathrm{C}}=\mathrm{O}), 55.42\left(p-\mathrm{OCH}_{3}^{\prime}, \mathrm{OCH}_{3}^{\prime \prime}\right.$ are merged together), 135.39 - 113.80 (aromatic and thienoyl ring carbons).

2r, 4c-Bis (p-fluorophenyl)-3-azabicyclo [3.3.1] nonan-9-one-2'-thienoyl hydrazone 12

IR (KBr) ( $\left.\mathrm{cm}^{-1}\right)$ : 3024.38, 2920.23, 2848.86 (C-H stretching), 3300.20 (-NH-), 1633.71 (C=O stretching), $1510.26\left(>\mathrm{C}=\mathrm{N}\right.$ stretching), ${ }^{1} \mathrm{H}$ NMR $\left(\mathrm{CDCl}_{3}, \delta \mathrm{ppm}\right): 10.311$ (s, $\left.1 \mathrm{H}, \mathrm{HN}-\mathrm{C}=\mathrm{O}\right), 4.437$ (t, 2H, H-2a and H-4a are merged together), 3.283 (s, 1H, H-5e), 2.849 (d, 1H, H-7a), 2.737 (s, 1H, H-1e), 1.915 (d, 2H, H-8e, H-6a), 1.758 - 1.676 (m, 3H, H-8a, H-6e and ring NH), 1.462 (d, 1H, H-7e), $8.244-7.144$ (m, 11H, aromatic and thienoyl ring protons). ${ }^{13} \mathrm{C}$ NMR ( $\left.\delta \mathrm{ppm}\right): 64.14$ (C-2), 62.97 (C-4), 46.04 (C-1), 38.38 (C-5), 28.94 (C-8), 27.05 (C-6), 21.11 (C-7), 143.38 (C-2'), 141.40 (C-4'), 163.43 (C-9), 160.99 (HN-C=O), 136.34 - 115.25 (aromatic and thienoyl ring carbons).

2r, 4c-Bis (p-chlorophenyl)-3-azabicyclo [3.3.1] nonan-9-one-2'-thienoyl hydrazone $\mathbf{1 3}$

IR (KBr) $\left(\mathrm{cm}^{-1}\right)$ : 3041.74, 2924.09, 2854.65 (C-H stretching), 3309.85 (-NH-), 1633.71 (C=O stretching), 1485.19 ( $>\mathrm{C}=\mathrm{N}$ stretching), ${ }^{1} \mathrm{H}$ NMR $\left(\mathrm{CDCl}_{3}, \delta \mathrm{ppm}\right): 10.579$ (s, $\left.1 \mathrm{H}, \mathrm{HN}-\mathrm{C}=\mathrm{O}\right), 4.489$ (s, 1H, H-2a), 4.419 (d, 1H, H-4a), 3.437 (s, 1H, H-5e), 2.779 (d, 2H, H-7a and H-1e are merged together), 1.904 - 1.596 (m, 5H, H-8e, H-6a, H-8a, H-6e and ring NH), 1.447 (s, 1H, H-7e), 8.20 - 7.202 (m, 11H, aromatic and thienoyl ring protons). ${ }^{13} \mathrm{C}$ NMR $(\delta \mathrm{ppm}): 64.12(\mathrm{C}-2), 62.86$ (C-4), 45.85 (C-1), 38.25 (C-5), 28.95 (C-8), $27.21(\mathrm{C}-6), 21.43$ (C-7), 143.34 (C-2'), 140.66 (C-4'), 164.01 (C-9), $161.51(\mathrm{HN}-\underline{\mathrm{C}}=\mathrm{O}), 140.30$ - 126.42 (aromatic and thienoyl ring carbons).

2r, 4c-Bis (p-bromophenyl)-3-azabicyclo [3.3.1] nonan-9-one-2'-thienoyl hydrazone 14

IR (KBr) $\left(\mathrm{cm}^{-1}\right)$ : 3039.81, 2966.52, 2922.16 and 2854.65 (C-H stretching), 3300.20 (-NH-), 1639.49 (C=O stretching), 1512.19 (>C=N stretching), ${ }^{1} \mathrm{H}$ NMR $\left(\mathrm{CDCl}_{3}, \delta \mathrm{ppm}\right): 10.519$ (s, $\left.1 \mathrm{H}, \mathrm{HN}-\mathrm{C}=\mathrm{O}\right), 4.465$ (s, $\left.1 \mathrm{H}, \mathrm{H}-2 \mathrm{a}\right)$, 4.395 (s, 1H, H-4a), 3.471 (s, 1H, H-5e), 2.798 (m, 2H, H-7a, H-1e are merged together), 1.905 - 1.759 (m, 5H, H-8e, H-6a, H-8a, H-6e and ring NH are merged together), 1.441 (s, 1H, H-7e), 8.229 - $7.206(\mathrm{~m}, 11 \mathrm{H}$, aromatic and thienoyl ring protons). ${ }^{13} \mathrm{C}$ NMR $(\delta \mathrm{ppm}): 64.16$ (C-2), 62.92 (C-4), 42.78 (C-1), 38.20 (C-5), 28.95 (C-8), 27.04 (C-6), 21.42 (C-7), 140.75 (C-2'), 140.04 (C-4'), 164.58 (C-9), 163.31 (HN-C=O), 134.80 - 121.23 (aromatic and thienoyl ring carbons).

2r, 4c-Bis ( $p$-isopropylphenyl)-3-azabicyclo [3.3.1] nonan-9-one-2'-thienoyl hydrazone 15

IR (KBr) $\left(\mathrm{cm}^{-1}\right)$ : 3026.31, 2958.80, 2864.29, 2926.01 (C-H stretching), 3304.06 (-NH-), 1635.64 (C=O stretching), 1514.12 (>C=N stretching), ${ }^{1} \mathrm{H}$ NMR $\left(\mathrm{CDCl}_{3}, \delta \mathrm{ppm}\right)$ : 10.625 (s, $\left.1 \mathrm{H}, \mathrm{HN}-\mathrm{C}=\mathrm{O}\right), 4.505$ (s, $\left.1 \mathrm{H}, \mathrm{H}-2 \mathrm{a}\right)$, 4.419 (d, 1H, H-4a), 3.472 (s, 1H, H-5e), 2.990 (d, 3H, H-7a and p-isopropyl CH' \& $\mathrm{CH}^{\prime \prime}$ ), 2.789 (s, 1H, H-1e), 1.977 (d, 2H, H-8e, H-6a), 1.716 - 1.594 (m, 3H, H-8a, H-6e and ring NH) 1.449 (d, 1H, H-7e), 1.337 (d,12H, p-isopropyl $\mathrm{CH}_{3}^{\prime} \& \mathrm{CH}_{3}^{\prime \prime} 8.229-7.182\left(\mathrm{~m}, 11 \mathrm{H}\right.$, aromatic and thienoylring protons) ${ }^{13} \mathrm{C}$ NMR

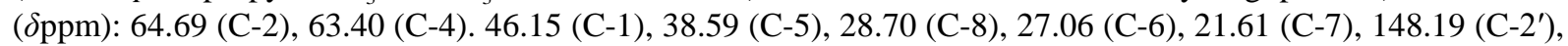
147.95 (C-4'), 163.84 (C-9) , 162.63 ( $\mathrm{HN}-\mathrm{C}=\mathrm{O}), 24.19$ - 23.86 (p-isopropyl $\left.\mathrm{CH}_{3}^{\prime}, \mathrm{CH}_{3}^{\prime \prime}, \mathrm{CH}_{3}^{\prime \prime \prime} \quad \mathrm{CH}_{3}^{\prime \prime \prime}\right), 34.05$ (p-isopropyl $\mathrm{CH}^{\prime} \quad \& \quad \mathrm{CH}^{\prime \prime}$ ), 139.96 - 126.23 (aromatic and thienoylring carbons).

\subsection{Pharmacology}

\subsubsection{In Vitro Antioxidant Activity}

The antioxidant capacity was measured by the 2, 2-Diphenyl-1-picrylhydrazyl (DPPH) explained by Blois [21]. Hydroxyl radical $\left(\mathrm{OH}^{*}\right)$ scavenging capacity was described by the method of Ren et al., (2008) [22] on the basis 
of the ability to complete with deoxyribose for $\mathrm{OH}^{*}$. Superoxide anions resulting from dissolved oxygen by a PMS/NADH coupling reaction reduced nitro blue tetrazolin (NBT) was evaluated by the procedure of Garrat et al. (1964) [23]. Scavenging capacity carried out triplicate of each sample and read at $515 \mathrm{~nm}$ using a micro plate reader (EL-800 Bio Tac instrument, Winoski, VT, USA). The percentage of scavenging assay DPPH*, $\mathrm{OH}^{*}$ and $\mathrm{O}_{2}^{--}$was calculated using the following formula

$$
\text { Free radical scavenging activity }(\%)=[(A c-A s) / A c] \times 100
$$

where Ac is the absorbance of control and As is absorbance of sample. BHT (Butylated hydroxytoluene) was used as standard drug. Which was calculated based on its concentration of compound required to reduce free radicals by $50 \%\left(\mathrm{IC}_{50}\right)$ as follows.

\subsubsection{Cell Culture and Preservation}

Human liver cancer cell lines (HepG2) were obtained from the National centre for cell sciences (NCCS). Pune, India. The cells cultivated in 0.5 mg MTT (3, [4, 5-dimethythiazole-2-yl] 2, 5-diphenyl tetrazolium bromide)/ML. of serum free DMEM (Dulbecco's modified Eagle's medium) at $37^{\circ} \mathrm{C}$ with $5 \% \mathrm{CO}_{2}$ and $95 \%$ air in a $\mathrm{CO}_{2}$ incubator. The viability of cells was measured by MTT assay (Mosmann, 1983) [24] using the HepG2 cell lines. The cell lines were treated with various concentrations of test compounds (3.12, 6.25, 12.50, 25 and $50 \mu \mathrm{g} / \mathrm{mL}$ ) for $24 \mathrm{~h}$. The $50 \%$ inhibitory concentration values $\left(\mathrm{IC}_{50}\right)$ of all experiments of test compounds were done using three replicates. Cytotoxicity was detected by using Graph pad prism 5 software.

\subsubsection{Apoptosis Detection of Nuclear Morphology}

Cells were stained with $0.5 \mathrm{~mL}$ of Hoechst 33342 solution $(3.5 \mu \mathrm{g} / \mathrm{mL})$ and incubated for $30 \mathrm{~min}$ at $37^{\circ} \mathrm{C}$ incubator. The Hoechst dyes can also be obtained from molecular probs. H342 is a "vital" DNA stain that binds preferentially to A-T base pains. Cells should be approximately $1.2 \times 10^{6} \mathrm{~mL}$ in buffered media, $\mathrm{pH}$ 7.2. It is also useful to include 2 percent fetal half cell serum (FCS) to maintain the cell, and measured by fluorescence microscope at $490-520 \mathrm{~nm}$ [25]. Apoptotic cell were defined on the mass of nuclear morphology changes such as chromatin condensation and fragmentation. Early apoptotic cells show navy blue fluorescence.

\subsubsection{In Vitro Antibacterial and Antifungal Activity}

Minimum inhibitory concentration (MIC) in $\mu \mathrm{g} / \mathrm{mL}$ values were found out by two-fold serial dilution method [26]. Bacterial strain namely Staphylococcus aureus. Escherichia coli, Klebsiella pheumoniae, pseudomonas aeruginosa and Salmonella typhi and fungal strain namely Cryptococcus neoformans, Candida albicans, Rizopus sp, Aspergillus nigar and Aspergillus flavus, were obtained from Faculty of medicine, Annamalai University, Annamalai Nagar, 608002, India. Seeded broth (broth containing microbial sporus) was prepared in NB from 24 hours old bacterial cultures on nutrient ager (Himedia, Mumbai) at $37^{\circ} \mathrm{C}$ while fungal strains were cultures in sabourauds dextrose broth (SDB). Testing was performed at $\mathrm{pH} 7.4 \pm 0.2$ for bacteria (NB) and at a $\mathrm{pH} 5.6$ for fungi (SDB). Plating techniques were used to determine the colony forming units (cfu) of the seeded broth in the adjusted range of $10^{4}$ to $10^{5} \mathrm{cfu} / \mathrm{mL}$ and 1.1 to $1.5 \times 10^{2} \mathrm{cfu} / \mathrm{mL}$ were the final inoculums size for antibacterial and antifungal assay, respectively. The respective test compounds 9-15 were dissolved in dimethyl sulphoxide (DMSO) to obtain $1 \mathrm{mg} / \mathrm{mL}$ stock solution. The growth of the microbes in the test medium was measured on the turbidity of the culture after 24 hours of bacterial incubation and 72 - 96 hours of fungal incubation.

\subsubsection{Statistical Analysis}

All investigated data were presented as the percentage of Mean \pm SEM (standard error of mean) of at least three individual experiments. Statistical analysis was performed with One-way ANOVA test analysis using the prism 5 statistical software package (graph pad software. USA). Differences were considered as being significant probability at $\mathrm{p}<0.005$.

\section{Results and Discussion}

\subsection{Chemistry}

The structural elucidation and stereochemistry of target compounds 9-15 were assigned by IR and NMR spectral 
data. Their purities were checked by elemental analysis Table 1. For compound $\mathbf{9}$, proton NMR ${ }^{1} \mathrm{H}$ and ${ }^{13} \mathrm{C}$ NMR signal were assigned unambiguously using two-dimensional spectra.

\subsection{Numbering of Atoms}

Figure 1 shows the numbering pattern of the bicyclo [3.3.1] nonane part. The ipso carbons of the phenyl rings at C-2 and C-4 are designated as C-2" and C-4", respectively. The other carbons of the phenyl ring at C-2 are denoted also $o, m$ and $p$ carbons and those of the phenyl ring at C-4 were denoted as $o^{\prime}, m^{\prime}, p^{\prime}$, carbons. Protons are numbered accordingly. Thiophene ring sulpfur atom was denoted as $1^{\prime}$. For illustrated, the benzyl proton at C-2 was denoted as $\mathrm{H}-2$, C-4 was denoted as $\mathrm{H}-4$ and so on. The methylene protons in the cyclohexane ring are

Table 1. Elemental analytical data of titled compound 9-15.

\begin{tabular}{cccccccccc}
\hline \multirow{2}{*}{$\begin{array}{c}\text { Comp } \\
\text { ound }\end{array}$} & $\begin{array}{c}\text { Molecular } \\
\text { Formula }\end{array}$ & $\begin{array}{c}\text { Molecular } \\
\text { weight }\end{array}$ & $\begin{array}{c}\text { Melting } \\
\text { Point }{ }^{\circ} \mathrm{C}\end{array}$ & $\begin{array}{c}\text { Yield } \\
\%\end{array}$ & & \multicolumn{4}{c}{ Elemental analysis found ${ }^{*}$ (calculated) in \% } \\
\cline { 8 - 9 } & & & & $\mathrm{C}$ & $\mathrm{H}$ & $\mathrm{N}$ & $\mathrm{S}$ \\
\hline 9 & $\mathrm{C}_{25} \mathrm{H}_{25} \mathrm{~N}_{3} \mathrm{OS}$ & 415.55 & 216 & 93 & $72.52(72.26)$ & $6.32(6.06)$ & $10.42(10.11)$ & $7.52(7.72)$ \\
10 & $\mathrm{C}_{27} \mathrm{H}_{29} \mathrm{~N}_{3} \mathrm{OS}$ & 443.60 & 220 & 89 & $73.35(73.10)$ & $6.34(6.59)$ & $9.68(9.47)$ & $7.43(7.23)$ \\
11 & $\mathrm{C}_{27} \mathrm{H}_{29} \mathrm{~N}_{3} \mathrm{O}_{3} \mathrm{~S}$ & 475.60 & 204 & 88 & $68.37(68.18)$ & $6.21(6.15)$ & $8.76(8.84)$ & $6.58(6.74)$ \\
12 & $\mathrm{C}_{25} \mathrm{H}_{23} \mathrm{~F}_{2} \mathrm{~N}_{3} \mathrm{OS}$ & 451.53 & 224 & 78 & $66.56(66.50)$ & $5.32(5.13)$ & $9.33(9.31)$ & $7.47(7.10)$ \\
13 & $\mathrm{C}_{25} \mathrm{H}_{23} \mathrm{Cl}_{2} \mathrm{~N}_{3} \mathrm{OS}$ & 484.44 & 210 & 81 & $61.69(61.98)$ & $4.58(4.79)$ & $8.57(8.67)$ & $6.59(6.62)$ \\
14 & $\mathrm{C}_{25} \mathrm{H}_{23} \mathrm{Br}_{2} \mathrm{~N}_{3} \mathrm{OS}$ & 573.34 & 217 & 82 & $52.34(52.37)$ & $4.28(4.04)$ & $7.36(7.33)$ & $5.89(5.59)$ \\
15 & $\mathrm{C}_{31} \mathrm{H}_{37} \mathrm{~N}_{3} \mathrm{OS}$ & 499.71 & 209 & 89 & $74.56(74.51)$ & $7.32(7.46)$ & $8.77(8.41)$ & $6.37(6.42)$ \\
\hline
\end{tabular}

*The measured values for $\mathrm{C}, \mathrm{H}, \mathrm{N}$ and $\mathrm{S}$ were within $\pm 0.4 \%$ of the theoretical values.

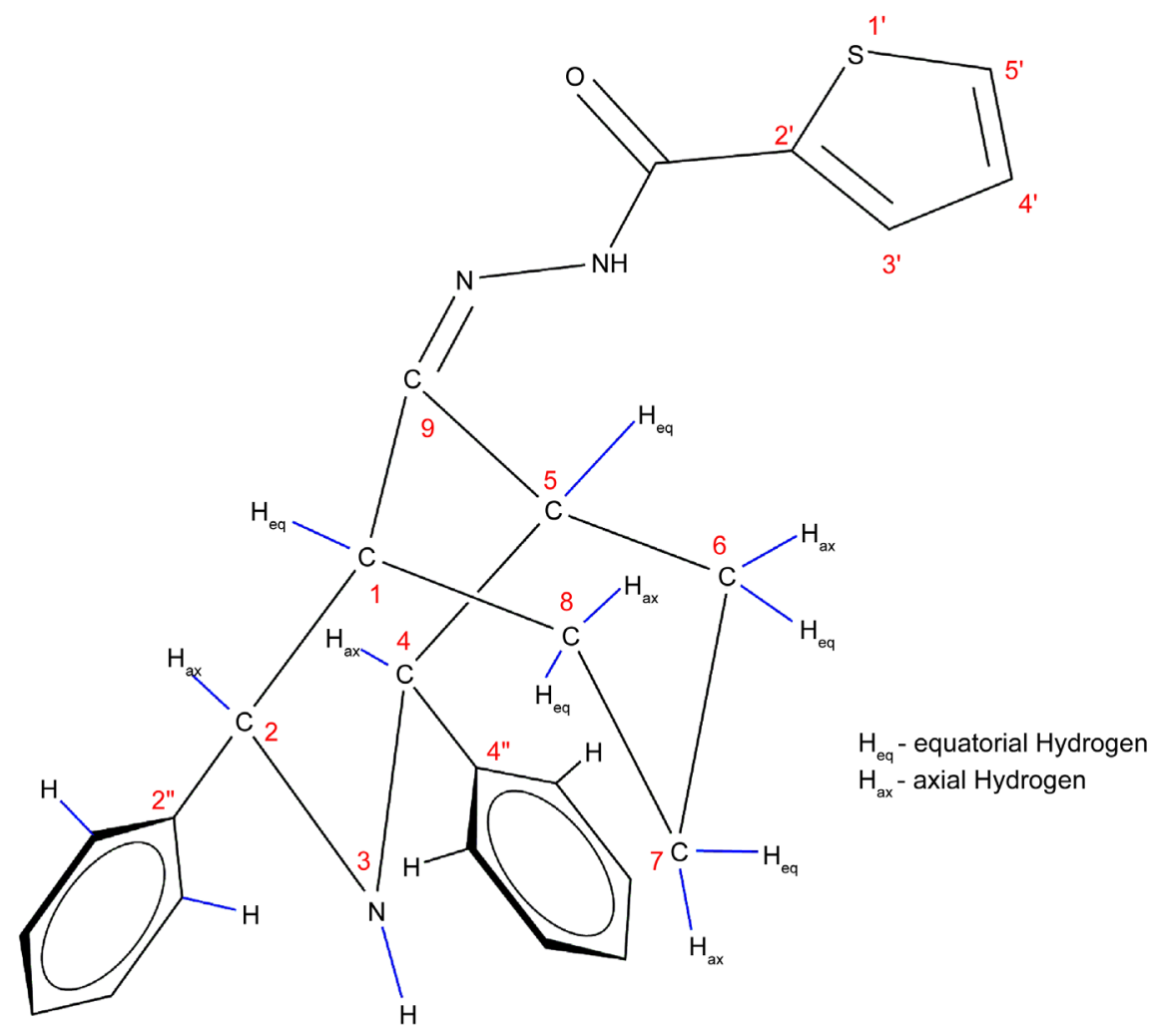

Figure 1. Numbering of the atoms. 
assigned as axial and equatorial protons assuming chair conformation for the cyclohexanone ring. C-7 protons are denoted as H-7a and H-7e.

\subsection{IR Spectral Analysis}

Hydrazones formation were assigned by $\mathrm{C}=\mathrm{N}$ stretching frequency at present in the range of $1485-1516 \mathrm{~cm}^{-1}$. The bicyclic NH stretching frequency was in the range $3300-3309 \mathrm{~cm}^{-1}$ and the amide $(\mathrm{C}=\mathrm{O})$ stretching frequency was in the range $1633-1641 \mathrm{~cm}^{-1}$. The amide NH stretching frequency was in the range $3024-3163$ $\mathrm{cm}^{-1}$, the adsorption band in the region of $2845-3041 \mathrm{~cm}^{-1}$ were attributed to aromatic, thienoyl ring and aliphatic C-H stretching frequencies [8].

\section{4. ${ }^{1} \mathrm{H}$ NMR Spectral Analysis}

For compound 9 the ${ }^{1} \mathrm{H}$ NMR signals were unambiguously assigned based on the observed correlation in the two dimensional (2D) NMR spectra. A broad and down field singlet at $10.21 \mathrm{ppm}$ was characteristic of the NH amide group. Signal broadening is due to the faster exchange of NH proton with solvent moisture than the resonance time scale. $\mathrm{NH}$ proton of the bicyclic ring and $\mathrm{H}-8 \mathrm{a} \& \mathrm{H}-6 \mathrm{e}$ protons were merged together and appeared as multiplets at $1.59 \mathrm{ppm}$. However, signal that appeared at 2.76 and $3.34 \mathrm{ppm}$ should be due to its bridgehead protons $\mathrm{H}-1 \mathrm{e}$ and $\mathrm{H}-5 \mathrm{e}$, respectively. Two signals appeared at 4.49 and $4.39 \mathrm{ppm}$ corresponds to each one proton integral. Furthermore, these two signal strong NOE shown in Figure 2, with doublet at $7.64 \mathrm{ppm}$ and singlet at $2.76 \& 3.34 \mathrm{ppm}$. Hence unambiguity, these two signals are attributed to benzylic protons $\mathrm{H}-2 \mathrm{a}$ and $\mathrm{H}-4 \mathrm{a}$. However, peaks at 2.76 and 3.34 ppm have been weak COSY correlation Figure 3 with benzylic protons and strong correlation with H-6a (1.88 ppm) and H-8a (1.59 ppm). H-1e and H-5e signal, one was highly deshielded

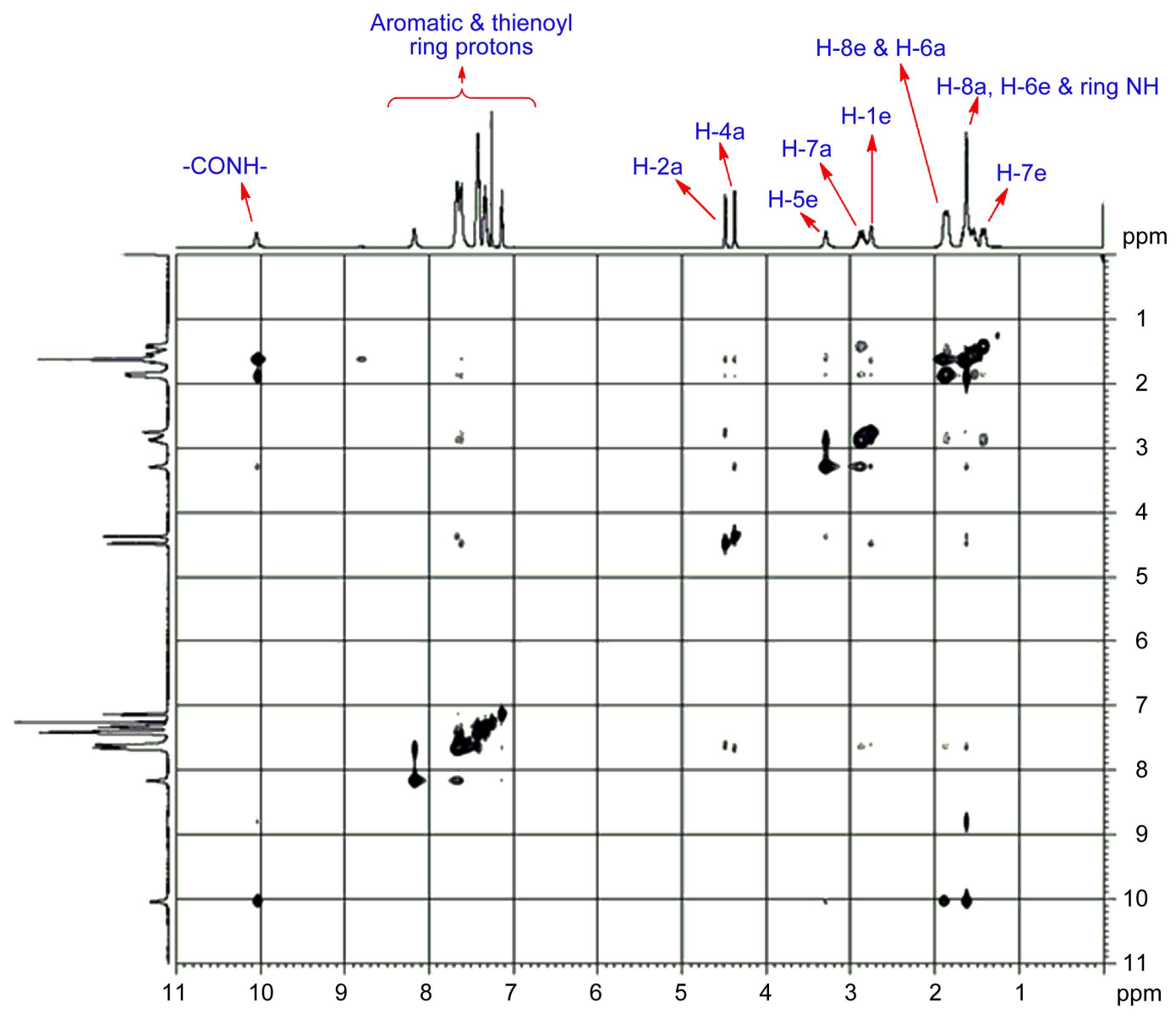

Figure 2. NOESY Spectrum of compound $\mathbf{9}$. 


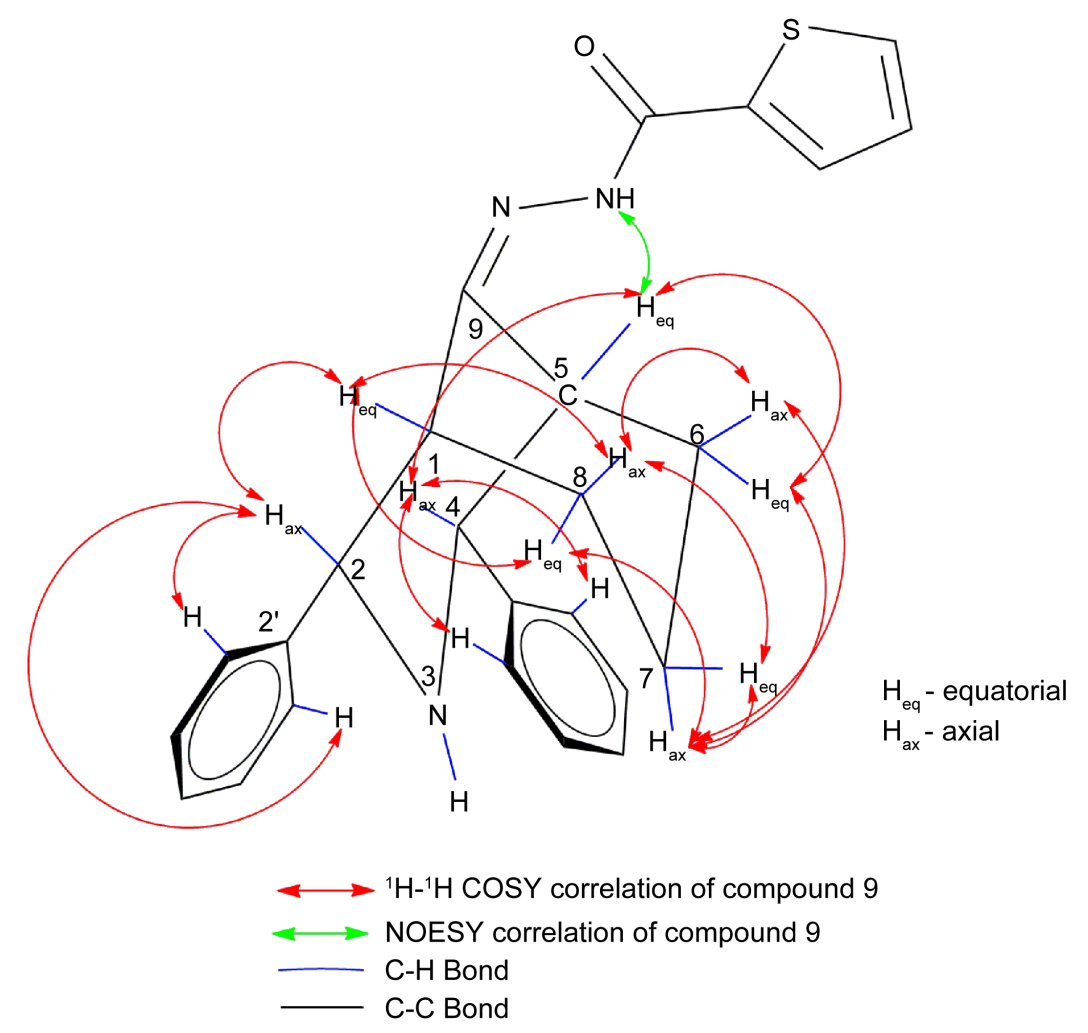

Figure 3. ${ }^{1} \mathrm{H}-{ }^{1} \mathrm{H}$ COSY and NOESY correlations of compound 9.

due to special interaction between the nitrogen (>CONH-) of thienoyl hydrazone analogue and one of the bridgehead proton. Outstanding to this interaction, partial charges created between them [27]. As a result, the bridge head $\alpha$-carbon acquires slight negative (-ve) charge and the attached proton gets slight (+ve) charge as shown in Figure 4. From this, the deshielded signal can be unambiguously assigned to syn $\alpha(\mathrm{H}-5)$ bridgehead proton whereas shielded signal was assigned to anti $\alpha(\mathrm{H}-1)$ proton.

Among the two observed signal $1.59 \mathrm{ppm}$ and $1.88 \mathrm{ppm}$ were deshielded signal assigned to $\mathrm{H}-6 \mathrm{e}$ and $\mathrm{H}-8 \mathrm{e}$ protons and the shielded one was assigned to H-6a and H-8a protons. Furthermore, the signals for C-7 protons were magnetically nonequivalent and observed at 2.87 and 1.41 ppm respectively for H-7a and H7e. H-7a proton were deshielded due to deshieding creates vanderwaals interaction. Therefore H-7a proton was highly deshielded than H-7e proton ${ }^{1} \mathrm{H}-{ }^{1} \mathrm{H}$ COSY correlation chemical shift of compound 9 shown in Figure 5, H-2 and $\mathrm{H}-4$ proton have also shown a cross peak with doublet at $7.64 \mathrm{ppm}$ which suggest that the signal have four protons integral is due to ortho protons of phenyl ring. All the aromatic and thienoyl ring protons which were collectively resonate between 7.13 to $8.16 \mathrm{ppm}$. All these surveillance were consistent with twin-chair (CC) conformation for this compound $\mathbf{9}$. For all other target compounds the ${ }^{1} \mathrm{H}$ signal were assigned by comparison with compound 9.

\section{5. ${ }^{13}$ C NMR Spectral Analysis}

In ${ }^{13} \mathrm{C}$ NMR spectral of synthesized compound 9, two downfield signals 163.56 and $161.81 \mathrm{ppm}$ were assigned for $\mathrm{C}=\mathrm{N}$ and $\mathrm{C}=\mathrm{O}$ carbons, respectively. However, there were two resonance carbon signals at 65.47 and 63.60 ppm is respectively due to C-2 and C-4 carbons. Furthermore, the carbon concerned in the fusion part C-5 and C-1 were consigned from the downfield signal at 38.41 and $46.09 \mathrm{ppm}$, respectively. The methylene carbons signal C-6, C-7 and C-8 of cyclohexanone were assigned in the region of 27.34, 21.56, and $28.56 \mathrm{ppm}$, respectively. Aromatic, ipso and thienoyl hydrazone carbons were assigned with admiration to their ${ }^{1} \mathrm{H}-{ }^{13} \mathrm{C}$ COSY (HSQC) correlations shown in Figure 6. Assignments for the other synthesized compounds 10-15 were made by comparison with compound $\mathbf{9}$. X-ray crystallographic study established that 2r, 4c-diphenyl-9t-ethynyl-3-azabicyclo [3.3.1] nonan-9t-ol exists in twin chair conformation with equatorial orientations of the aryl groups [28]. 


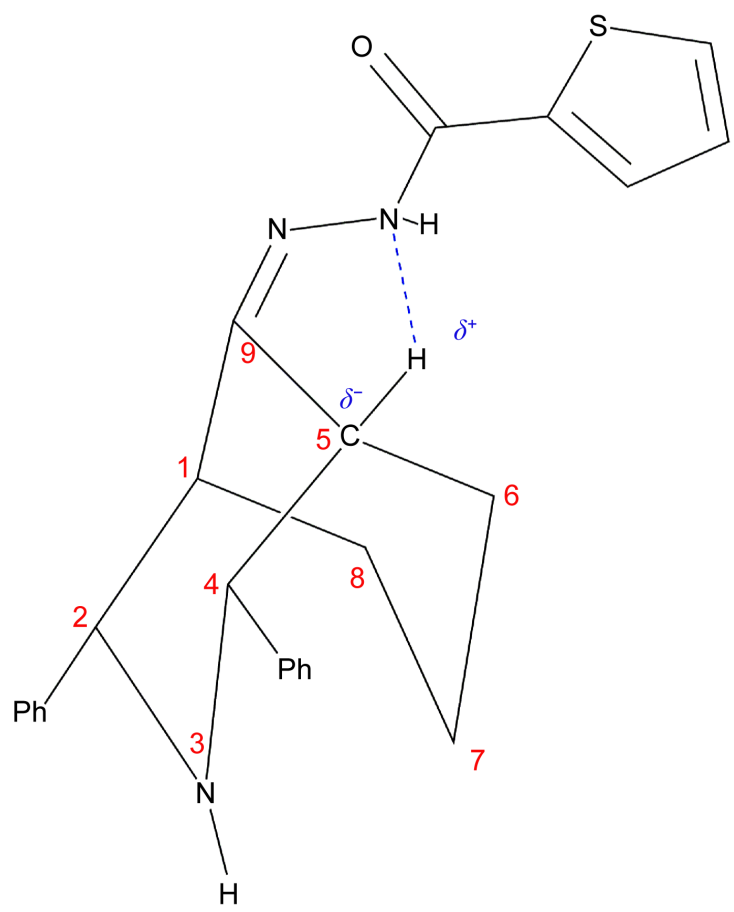

Figure 4. Non-bonded interaction between $\mathrm{H}-5 \mathrm{e}$ and nitrogen (thienoyl hydrazone $\underline{\mathbf{N}} \mathrm{HCO}$ ).

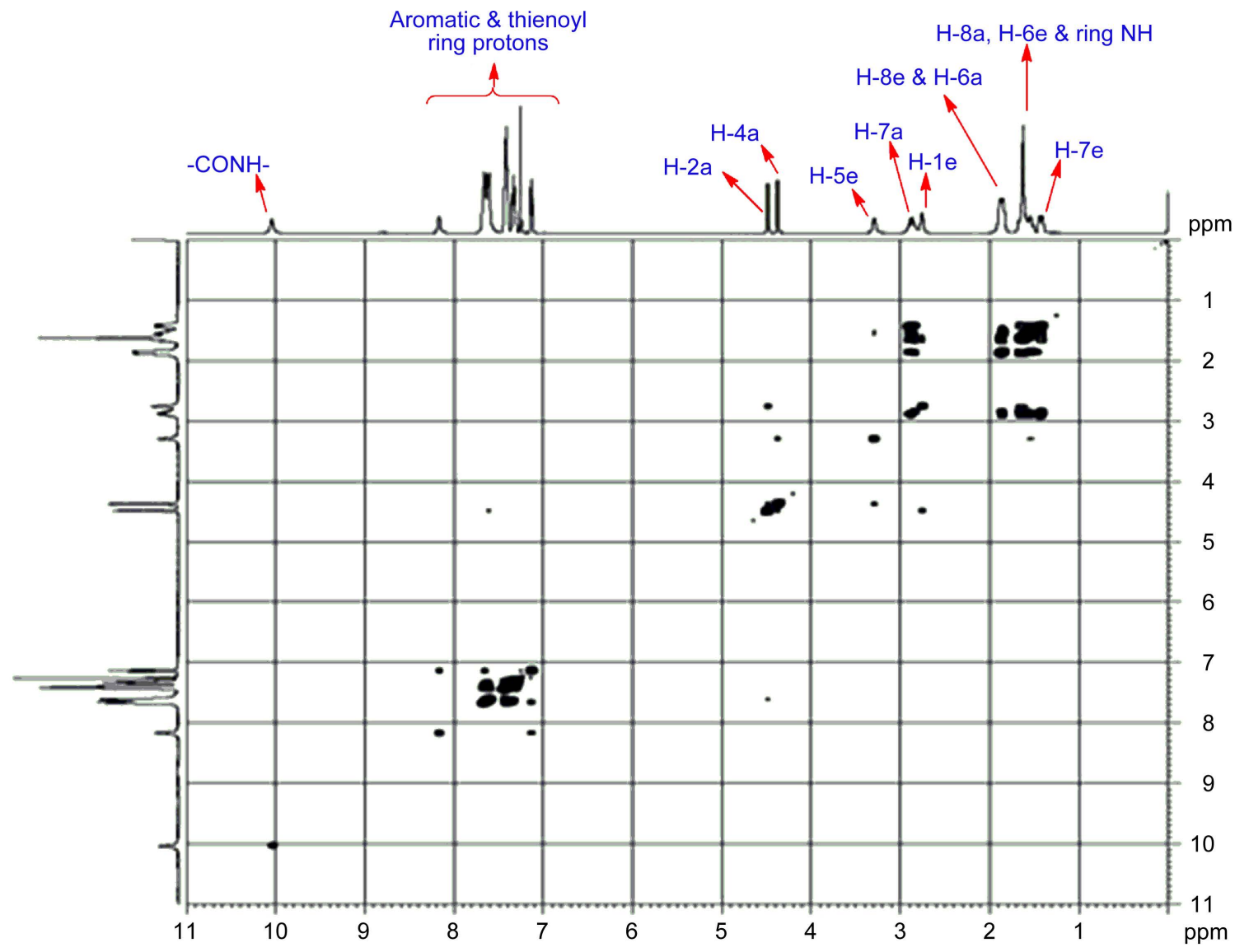

Figure 5. ${ }^{1} \mathrm{H}-{ }^{1} \mathrm{H}$ COSY Spectrum of compound 9. 


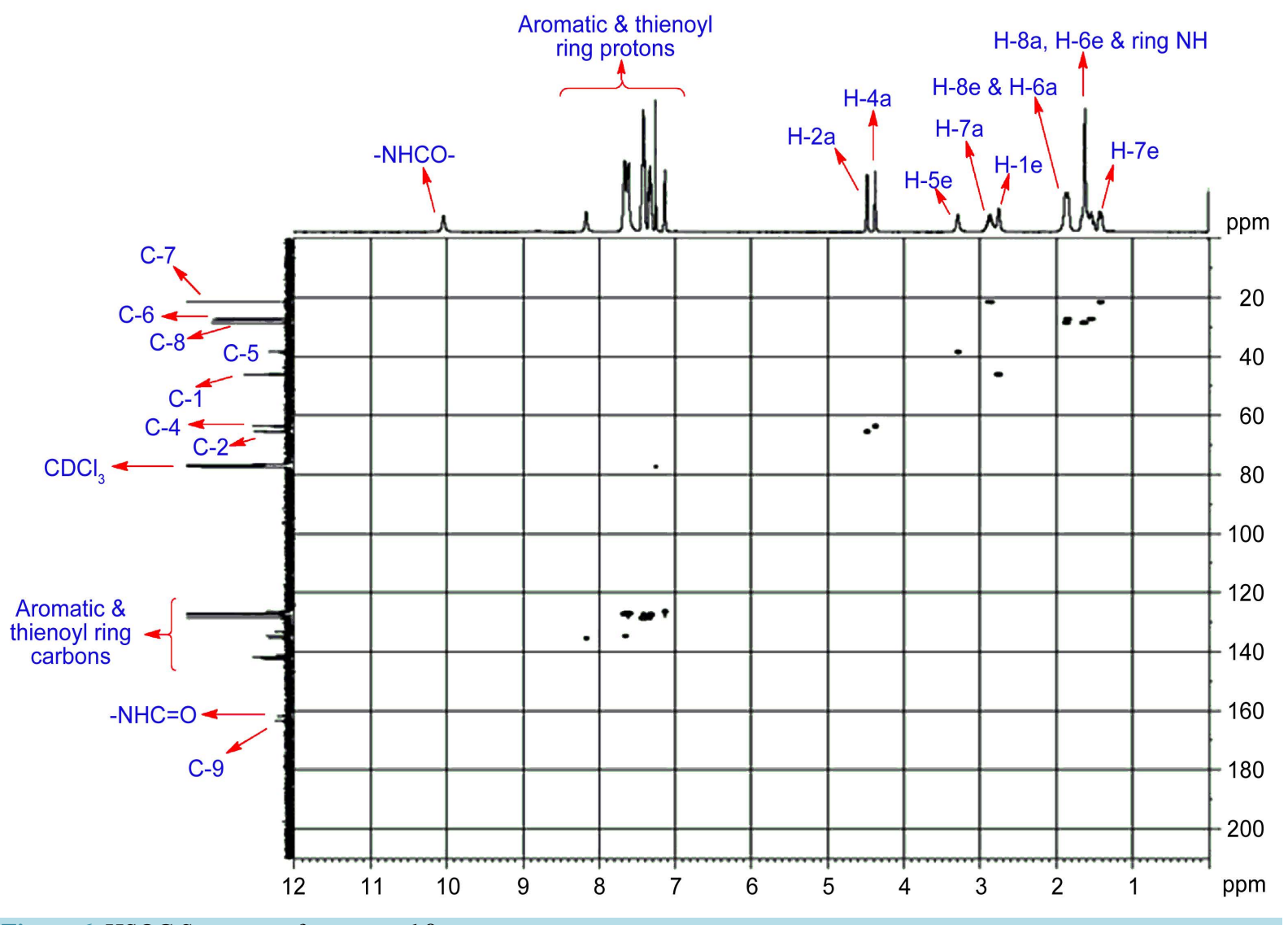

Figure 6. HSQC Spectrum of compound $\mathbf{9}$.

Taken together, all of the above observations substantiate planned structure and twin-chair (CC) conformation of 2r, 4c-diaryl-3-azabicyclo [3.3.1] nonan-9-one-2-thienoyl hydrazones (9-15).

\subsection{In Vitro Free Radical Scavenging Activity}

Seven various 2-thienoyl hydrazone derivatives 9-15 were examined for their in vitro antioxidant activity against $\mathrm{DPPH}^{*}, \mathrm{OH}^{*}$ and $\mathrm{O}_{2}^{--}$radicals. 50 percent (50\%) inhibitory concentration $\left(\mathrm{IC}_{50}\right)$ values for the free radical scavenging effect of BHT and various substituted synthetic compounds 9-15 were shown in Table 2. Free radical scavenging activity was treated with different concentration level 3.12, 6.25, 12.5, 25 and $50 \mu \mathrm{g} / \mathrm{mL}$. We reported that electron-donor methoxy $\left(\mathrm{OCH}_{3}\right)$ substitution compound $11\left(\mathrm{IC}_{50}\right.$ range $\left.3.78-4.31 \mu \mathrm{g} / \mathrm{mL}\right)$ showed excellent antioxidant capacity compared to other compounds and standard antioxidant, a known antioxidant used as a positive control shown in Figure 7. Tested with compound $\mathbf{9}$ devoid of any substituent at phenyl ring at C-2 and C-4 positions of the azabicyclo [3.3.1] nonan-9-one inhibited 50\% of the different free radicals at the concentration range $34.26-35.65 \mu \mathrm{g} / \mathrm{mL}$. Compound possessing electron withdrawing fluoro, chloro and bromo substitutions at the phenyl rings showed admirable in-vitro free radical scavenging effect against $\mathrm{DPPH}^{\circ}, \mathrm{OH}^{*}$ and $\mathrm{O}_{2}^{--}$radicals. Therefore, antioxidant capacity of all the synthesized compounds were in the decreasing order $11>15>10>9>14>13>12$.

\subsection{In Vitro Anticancer Activity}

Human liver cancers foremost reason for human death and malignancy throughout the world, according to survey 7.6 million death in 2010 century and anticipated to reach the figure of almost 13 million death by 2030 century, about 70\% cancers [29] [30]. The aim of present work challenged cytotoxic activity against on a panel of human liver hapatocellular carcinoma (HepG2) [31] was treated with the innovative target compound 9-15 significantly inhibited the proliferation of cancer cell lines in various concentrations manner (3.12, 6.25, 12.5, 25 
Table 2. Inhibitory concentration values $\left(\mathrm{IC}_{50}\right.$ ) for anti-oxidant activity of compound 9-15.

\begin{tabular}{ccccc}
\hline \multirow{2}{*}{ Compound } & $\mathbf{R}$ & \multicolumn{3}{c}{ IC $_{50}$ values } \\
\cline { 2 - 4 } & & $\mathbf{D P P H}$ & $\mathbf{O H}^{\bullet}$ & $\mathbf{O}_{2}^{-}$ \\
\hline 9 & $\mathrm{H}$ & $35.23 \pm 0.083$ & $35.65 \pm 0.056$ & $34.26 \pm 0.010$ \\
10 & $p-\mathrm{CH}_{3}$ & $8.09 \pm 0.074$ & $7.56 \pm 0.012$ & $8.49 \pm 0.098$ \\
11 & $p-\mathrm{OCH}_{3}$ & $3.78 \pm 0.056$ & $4.31 \pm 0.063$ & $4.23 \pm 0.063$ \\
12 & $p-\mathrm{F}$ & $41.44 \pm 0.053$ & $40.46 \pm 0.098$ & $40.26 \pm 0.057$ \\
13 & $p-\mathrm{Cl}$ & $37.92 \pm 0.077$ & $38.59 \pm 0.0925$ & $37.95 \pm 0.090$ \\
14 & $p-\mathrm{Br}$ & $35.01 \pm 0.084$ & $37.93 \pm 0.035$ & $36.97 \pm 0.091$ \\
15 & $p-\mathrm{CH}\left(\mathrm{CH}_{3}\right)_{2}$ & $4.61 \pm 0.071$ & $4.59 \pm 0.039$ & $5.16 \pm 0.093$ \\
$\mathbf{B H T}$ & - & $5.46 \pm 0.064$ & $5.66 \pm 0.013$ & $5.86 \pm 0.011$ \\
\hline
\end{tabular}

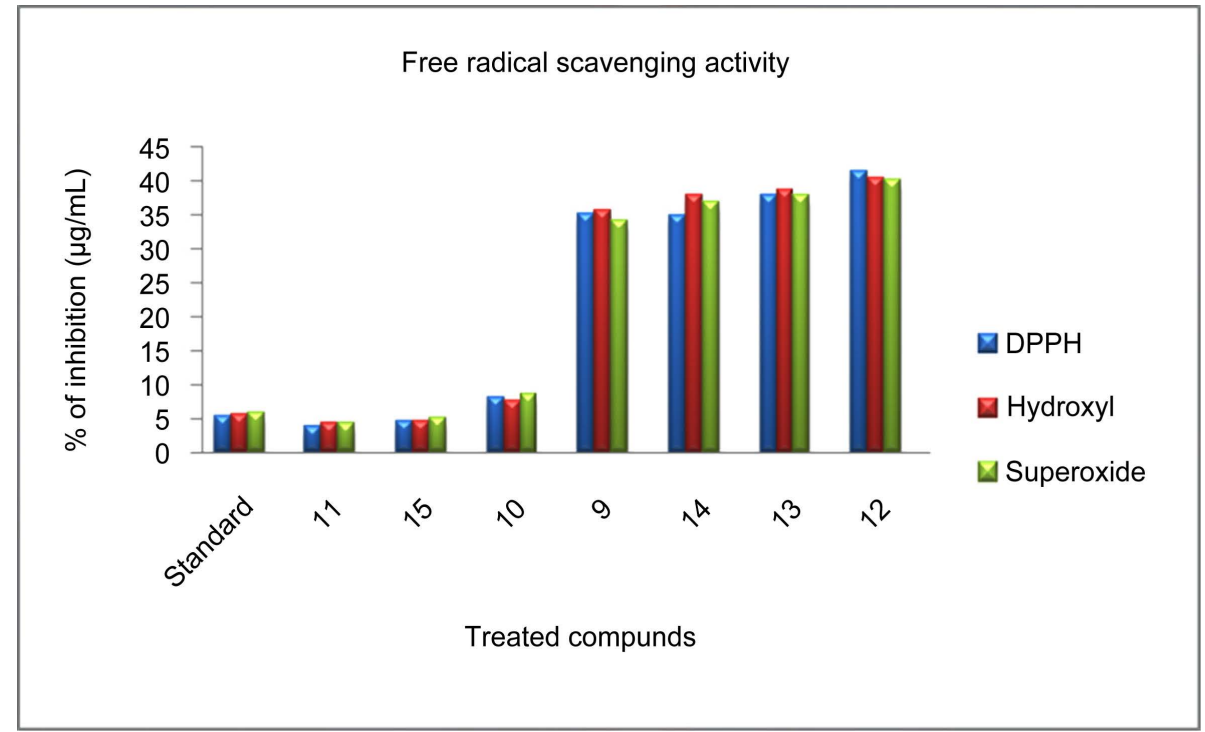

Figure 7. Antioxidant activity of standard (BHT) drug and synthesized compounds 9-15.

and $50 \mu \mathrm{g} / \mathrm{mL}$.), after 24 hours of incubation were examined by means of the MTT assay. IC $_{50}$ values for the cytotoxic effect of synthetic compounds were shown in Table 3 . The incorporation of electron withdrawing group such as $\mathrm{F}, \mathrm{Cl}$ and $\mathrm{Br}$ substitution at para position of C-2, C-4 diaryl rings of the 3-azabycyclo [3.3.1] nonan-9-one compounds 12, 13 and 14 exhibit more cytotoxicity than electron donating group such as $\mathrm{CH}_{3}$, $\mathrm{OCH}_{3}$ and $\mathrm{CH}\left(\mathrm{CH}_{3}\right)_{2}$ substitution at para position of C-2, C-4 diaryl rings of the 3-azabycyclo [3.3.1] nonan-9-one compounds 10, 11 and 15. Especially the compound $12\left(\mathrm{IC}_{50}=3.76 \mu \mathrm{g} / \mathrm{mL}\right)$ shows excellent cytotoxicity than compounds $\mathbf{1 3}$ and $\mathbf{1 4}$. We found the strong cytotoxicity with poor antioxidant property of synthesized compounds 12, 13 and 14 may be due to the pro-oxidant effect by halogens [11]. The overall cytotoxicity effect of synthesized compounds were in the decreasing order $\mathbf{1 2}>\mathbf{1 3}>\mathbf{1 4}>\mathbf{1 1}>\mathbf{1 5}>\mathbf{1 0}>\mathbf{9}$. However several mechanisms regulating the antioxidant and anticancer activity of hybrid molecule are needed for advance research.

\subsection{Discovery of Apoptosis by Hoechst Staining}

In treated and controlled cells, apoptosis in nuclear morphology by using Hoechst 33342 (H342) were experiential and compared in the Figure 8. Fluorescence microscopy analysis was used to assess the apoptotic feature in HepG2 cancer cells induced by fluoro substituted compound 12. The control showed normal health and whole nuclei without any cytomorphological abnormalities. The HepG2 cell lines were treated with 50\% inhibitory 
Table 3. Anticancer activity of target compounds (9-15) against human liver hepatocellular carcinoma cell lines (HepG2).

\begin{tabular}{|c|c|c|c|c|c|c|}
\hline \multirow{3}{*}{ Compound } & \multicolumn{5}{|c|}{ Compound concentrations $(\mu \mathrm{g} / \mathrm{mL})$} & \multirow{3}{*}{$\begin{array}{c}\text { Ic } c_{50} \text { values } \\
(\mu \mathrm{g} / \mathrm{mL})\end{array}$} \\
\hline & 3.12 & 6.25 & 12.50 & 25.00 & 50.00 & \\
\hline & \multicolumn{5}{|c|}{ Death cells (\% of Mean \pm SE) $)^{\mathbf{b}}$} & \\
\hline 9 & $5.371 \pm 0.029$ & $12.320 \pm 0.057$ & $20.595 \pm 0.042$ & $31.372 \pm 0.044$ & $57.291 \pm 0.024$ & 42.49 \\
\hline 10 & $12.277 \pm 0.035$ & $25.319 \pm 0.015$ & $34.144 \pm 0.041$ & $46.320 \pm 0.029$ & $81.963 \pm 0.023$ & 26.26 \\
\hline 11 & $21.275 \pm 0.042$ & $39.513 \pm 0.081$ & $48.544 \pm 0.037$ & $80.648 \pm 0.038$ & $97.286 \pm 0.068$ & 12.92 \\
\hline 12 & $39.312 \pm 0.044$ & $69.759 \pm 0.023$ & $84.536 \pm 0.002$ & $98.365 \pm 0.013$ & $>100$ & 3.76 \\
\hline 13 & $28.202 \pm 0.026$ & $47.343 \pm 0.060$ & $79.348 \pm 0.025$ & $89.341 \pm 0.015$ & $98.114 \pm 0.014$ & 6.94 \\
\hline 14 & $25.382 \pm 0.049$ & $41.325 \pm 0.012$ & $79.105 \pm 0.073$ & $89.405 \pm 0.100$ & $98.103 \pm 0.004$ & 8.10 \\
\hline 15 & $14.196 \pm 0.033$ & $25.347 \pm 0.063$ & $39.173 \pm 0.018$ & $78.252 \pm 0.014$ & $93.235 \pm 0.017$ & 17.52 \\
\hline
\end{tabular}

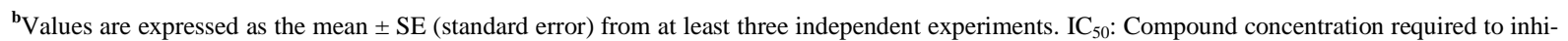
bit cancer cells proliferation by $50 \%$.
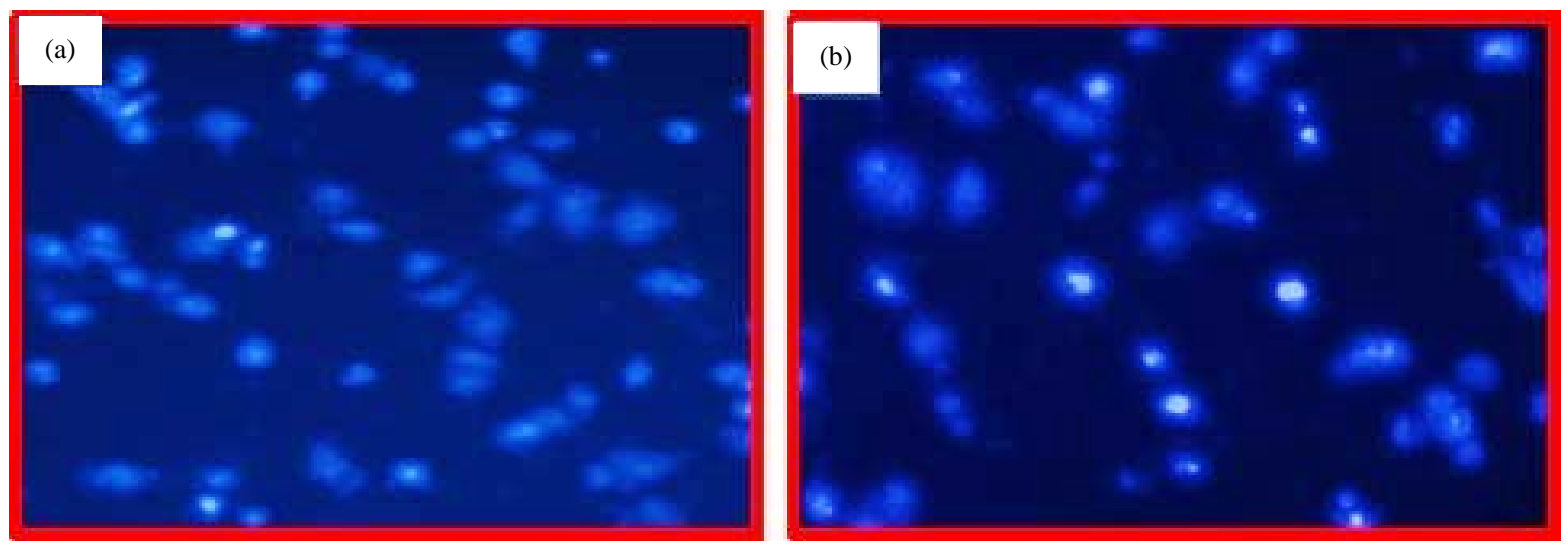

Figure 8. The effect of fluorescent microscope image of (a) control (b) the cell treated HepG2 cell lines with IC $_{50}$ concentration $3.76 \mu \mathrm{g} / \mathrm{mL}$ of the most active lead compound 12. Stained with Hoechst 33342 (H342). These cell lines detected by 490 - $520 \mathrm{~nm}$ of fluorescent microscope excitation/emission.

concentration among the efficient cytotoxic compound 12 and $\mathrm{IC}_{50}$ value is $3.76 \mu \mathrm{g} / \mathrm{mL}$ for 48 hours. The dark blue (navy blue) fluorescence indicated the viable cells while the bluish white fluorescence indicated the death cells. The above results of 490 - $520 \mathrm{~nm}$ of fluorescence microscopy using Hoechst stain control Figure 8(a) and treated HepG2 cell lines Figure 8(b). Bright condensed chromatin (pyknosis) and cell shrinkage was observed in these compound treated apoptotic cells. The report of the procedure, disintegration of the nucleus was also observed in the treated cell lines.

\subsection{In Vitro Antimicrobial Activity}

The in vitro antibacterial activity of synthesized compounds 9-15 were treated with bacterial strains viz., (S. aureus. E. coli, K. pheumoniae, p. aeruginosa and S. typhi) and were expressed as minimum inhibitory concentrations (MIC) in $\mu \mathrm{g} / \mathrm{mL}$. Streptomycin was taken as standard drug [32] and the observed MIC values were given in Table 4 Compound 12, 13 and 14 possessing para halo substitution at phenyl rings of azabicyclononane derivatives account for the superior inhibitory effect against $S$. aureus, $K$. pheumoniae and $S$. typhi at MIC values of $6.25 \mu \mathrm{g} / \mathrm{mL}$, and p. aeruginosa at MIC values of $12.50 \mu \mathrm{g} / \mathrm{mL}$ when compared to standard antibiotic streptomycin. Evidenced that electron withdrawing group substituted azabicyclononane derivatives exhibited marvelous antimicrobial activities [33]. Other target compound displayed reduced inhibitory effect against different bacterial strains compared to standard drug. The account of the present study also provide proof for the antifungal 
Table 4. In vitro antimicrobial screening of target compounds 9-15.

\begin{tabular}{|c|c|c|c|c|c|c|c|c|c|c|}
\hline \multirow{2}{*}{ Compounds } & \multicolumn{5}{|c|}{$\begin{array}{l}\text { Bacterial strains } \\
\text { Minimum inhibitory concentration (MIC) in } \mu \mathrm{g} / \mathrm{mL}\end{array}$} & \multicolumn{5}{|c|}{$\begin{array}{l}\text { Fungal strains } \\
\text { Minimum inhibitory concentration (MIC) in } \mu \mathrm{g} / \mathrm{mL}\end{array}$} \\
\hline & S. aureus & E. coli & K. pheumoniae & P.aeruginosa & S. typhi & C. albicans & C. neoformans & Rizopus. sp & A nigar & A. flavus \\
\hline 9 & 25 & 100 & 100 & 100 & 100 & 100 & 100 & 100 & 100 & 50 \\
\hline 10 & 25 & 50 & 50 & 50 & 25 & 50 & 100 & 50 & 50 & 50 \\
\hline 11 & 50 & 200 & 200 & 100 & 200 & 100 & 200 & 100 & 25 & 25 \\
\hline 12 & 6.25 & 12.5 & 6.25 & 25 & 6.25 & 6.25 & 6.25 & 6.25 & 12.5 & 12.5 \\
\hline 13 & 12.5 & 12.5 & 6.25 & 25 & 12.5 & 6.25 & 6.25 & 12.5 & 12.5 & 12.5 \\
\hline 14 & 12.5 & 12.5 & 6.25 & 12.5 & 12.5 & 6.25 & 12.5 & 6.25 & 12.5 & 12.5 \\
\hline 15 & 12.5 & 25 & 12.5 & 25 & 25 & 25 & 50 & 25 & 25 & 25 \\
\hline Standard ${ }^{*}$ & 12.5 & 25 & 12.5 & 12.5 & 12.5 & 25 & 25 & 25 & 25 & 25 \\
\hline
\end{tabular}

*Standard drug used: for antibacterial activity—Streptomycin, for antifungal activity—Amphotericin B.

effect of an array of 2-thienoyl hydrazones 9-15 with MIC values shown in the Table 4. Compound 12, 13 and 14 had enhanced inhibitory effect against all tested fungi strains and standard drug (Amphotericin B) of MIC range was 6.25 - $12.5 \mu \mathrm{g} / \mathrm{mL}$, and isopropyl substituted compound 15 exhibited identical potency compared to standard drug except $C$. neoformans strain. Other compounds exhibited mild inhibitory potency against different fungi strains compared to standard drug.

\section{Conclusion}

The report of the present study of 2-thienoyl hydrazones of 2r, 4c-diaryl-3-azabicyclo [3.3.1] nonan-9-ones in excellent yield, stereochemistry and characterized by elemental analysis and spectral data 1D and 2D NMR spectra. All of the above observations substantiate the proposed structure and twin-chair (CC) conformation of all target compounds 9-15. The compounds were evaluated various biological activities. Through the target compound with electron withdrawing such as $\mathrm{F}, \mathrm{Cl}, \mathrm{Br}$ substitution compounds were superior anticancer, antibacterial and antifungal activity. However, the electron donating substituted such as $\mathrm{CH}_{3}, \mathrm{OCH}_{3}$ and $\mathrm{CH}\left(\mathrm{CH}_{3}\right)_{2}$ compounds act great antioxidant activity than electron withdrawing substituted compounds. Studies on the structural mechanisms by which the new synthetic molecules put forth its anticancer, antioxidant, antibacterial and antifungal activity are making development and will be delivered in the prospect.

\section{Acknowledgements}

The authors were great thankful to The Department of Chemistry, Annamalai University, Tamilnadu, India, for the recording of the NMR spectral data's and providing all necessary facilities to found the present work successfully. We extend our gratitude to the RMMCH, Annamalai University for biological studies.

\section{References}

[1] (2013) Cancer. Fact Sheet No. 297, World Health Organization, Geneva. http://www.who.int/mediacentre/factsheets/fs297/en/.

[2] Poljsak, B., Suput, D. and Milisav, I. (2013) Achieving the Balance between ROS and Antioxidants: When to Use the Synthetic Antioxidants. Oxidative Medicine and Cellular Longevity, 2013, Article ID: 956792. http://dx.doi.org/10.1155/2013/956792

[3] Valko, M., Leibfritz, D., Moncol, J., et al. (2007) Free Radicals and Antioxidants in Normal Physiological Functions and Human Disease. International Journal of Biochemistry \& Cell Biology, 39, 44-84. http://dx.doi.org/10.1016/j.biocel.2006.07.001

[4] Kasai, H. and Kawai, K. (2006) Oxidative DNA Damage: Mechanisms and Significance in Health and Disease. Antioxidants \& Redox Signaling, 8, 981-983. http://dx.doi.org/10.1089/ars.2006.8.981

[5] Jayaraman, P. and Avila, S. (1981) Chemistry of 3-Azabicyclo [3.3.1] Nonanes. Chemical Reviews, 81, 149-174. 
http://dx.doi.org/10.1021/cr00042a002

[6] Hardick, D.I., Balagbrough, I.S., Cooper, G., Potter, B.V.L., Critchley, T. and Wonnacott, S. (1996) Nudicauline and Elatine as Potent Norditerpenoid Ligands at Rat Neuronal $\alpha$-Bungarotoxin Binding Sites: Importance of the 2-(Methylsuccinimido)benzoyl Moiety for Neuronal Nicotinic Acetylcholine Receptor Binding. Journal of Medicinal Chemistry, 39, 4860-4866. http://dx.doi.org/10.1021/jm9604991

[7] Barker, D., Lin, D.H.S., Crland, J.E., Chu, C.P.Y., Chebib, M., Brimble, M.A., Savage, C.P. and Mclead, M.D. (2005) Methyllycaconitine Analogues Have Mixed Antagonist Effects at Nicotinic Acetylcholine Receptors. Bioorganic \& Medicinal Chemistry, 13, 4565-4575. http://dx.doi.org/10.1016/j.bmc.2005.04.054

[8] Sankar, C. and Pandiarajan, K. (2010) Synthesis and Anti-Tubercular and Antimicrobial Activities of Some 2r, 4c-diaryl3-azabicyclo[3.3.1] Nonan-9-One N-Isonicotinoylhydrazone Derivatives. European Journal of Medicinal Chemistry, 46, 5480-5485. http://dx.doi.org/10.1016/j.ejmech.2010.08.024

[9] Ramachandran, R., Rani, M. and Kabilan, S. (2010) Synthesis, Structure and Conformational Analysis of 2,4-Diaryl-3Azabicyclo[3.3.1]nonan-9-One Thiosemicarbazones and Semicarbazones. Journal of Molecular Structure, 970, 42-50. http://dx.doi.org/10.1016/j.molstruc.2010.02.005

[10] Khaledi, H., Alhadi, A.A., Yehye, W.A., Ali, H.M., Abdulla, M.A. and Hassandarvish, P. (2011) Antioxidant, Cytotoxic Activities, and Structure-Activity Relationship of Gallic Acid-Based Indole Derivatives. Archiv der Pharmazie, 344, 703-709. http://dx.doi.org/10.1002/ardp.201000223

[11] Lee, C.Y., Sharma, A., Uzarski, R.L., Cheong, J.E., Xu, H., Held, R.A., Upadhaya, S.K. and Nelson, J.L. (2011) Potent Antioxidant Dendrimers Lacking Pro-Oxidant Activity. Free Radical Biology and Medicine, 50, 918-925. http://dx.doi.org/10.1016/j.freeradbiomed.2010.10.699

[12] Chitra, S., Devanathan, D. and Pandiarajan, K. (2010) Synthesis and in Vitro Microbiological Evaluation of Novel 4-Aryl-5-Isopropoxycarbonyl-6-Methyl-3,4-Dihydropyrimidinones. European Journal of Medicinal Chemistry, 45, 367-371. http://dx.doi.org/10.1016/j.ejmech.2009.09.018

[13] Rossi, C., Figini, A. and Corpi, A. (1968) Antiarrhythmic Action of Certain 1,5-Diphenyl-Bispidin Derivatives. Annali dell'Istituto Superiore di Sanità, 4, 333. (1969) Chemical Abstracts Service, 70, 85997s.

[14] Chivarelli, S., Delcarmine, R. and Michalek, H. (1972) Effect of Some Antiarrhythmic 1,5-Diphenyl-Bispidine Derivatives on in Vitro Oxygen Uptake and Glucose Utilization of Rat Heart Muscle. Annali dell' Istituto Superiore di Sanità, 8, 156. (1973) Chemical Abstracts Service, 78, 24098z.

[15] Binning, F., Friedrich, L., Hofmann, H.P., Kreiskoh, H., Raschack, M. and Muller, C. (1978) Neue Bispidinderivate, verfahren Zu deren Herstellung und Arzneimittel, Welche diese enthalten. German Patent No. 2726571. (1979) Chemical Abstracts Service, 90, 121568h.

[16] a) Ganellin, C.R. and Spickett, R.G.W. (1965) Compounds Affecting the Central Nervous System. I. 4-Piperidones and Related Compounds. Journal of Medicinal Chemistry, 8, 619-625. http://dx.doi.org/10.1021/jm00329a015

b) El-Subbagh, H.I., Abu-Zaid, S.M., Mahran, M.A., Badria, F.A. and Al-obaid, A.M. (2000) Synthesis and Biological Evaluation of Certain $\alpha, \beta$-Unsaturated Ketones and Their Corresponding Fused Pyridines as Antiviral and Cytotoxic Agents. Journal of Medicinal Chemistry, 43, 2915-2921. http://dx.doi.org/10.1021/jm000038m

[17] Olayinka, O.A., Craig, A.O., Obinna, C.N. and David, A.A. (2010) Microwave Assisted Synthesis and Antimicrobial Activity of 2-Quinoxalinone-3-Hydrazone Derivatives. Bioorganic \& Medicinal Chemistry, 18, 214-221. http://dx.doi.org/10.1016/j.bmc.2009.10.064

[18] Fang, V.S., Minkin, C. and Goldhaber, P. (1971) 2-Thiophenecarboxylic Acid: Inhibitor of Bone Resorption in Tissue Culture. Science, 172, 163-165. http://dx.doi.org/10.1126/science.172.3979.163

[19] Pratt, J.W. (2003) In: Wiley-VCH, Ed., Ullmann's Encyclopedia of Industrial Chemistry, Vol. 36, Wiley-VCH, Weinheim, 653.

[20] Baliah, V. and Jeyaraman, R. (1971) Synthesis of Some 3-Azabicyclo[3.3.1]Nonan-9-One. Indian Journal of Chemistry, 9, 1020-2022.

[21] Blois, M.S. (1958) Antioxidant Determinations by the Use of a Stable Free Radical. Nature, 26, 1199-1200. http://dx.doi.org/10.1038/1811199a0

[22] Ren, J.Y., Zhao, M.M., Shi, J., Wang, J.S., Jiang, Y.M., Cui, C., et al. (2008) Purification and Identification of Antioxidant Peptides from Grass Carp Muscle Hydrolysates by Consecutive Chromatography and Electrospray Ionization-Mass Spectrometry. Food Chemistry, 108, 727-736. http://dx.doi.org/10.1016/j.foodchem.2007.11.010

[23] Garratt, C.J. (1964) Effect of Iodination on the Biological Activity of Insulin. Nature, 201, 1324-1325. http://dx.doi.org/10.1038/2011324a0

[24] Mosmann, T. (1983) Rapid Colorimetric Assay for Cellular Growth and Survival: Application to Proliferation and Cytotoxicity Assays. Journal of Immunological Methods, 65, 55-63.

[25] Standar, A., Marais, S., Stivaktas, V., Vorster, C., Albrecht, C., Lottering, M.-L. and Joubert, A.M. (2009) In Vitro Ef- 
fects of Sutherlandia frutescens Water Extracts on Cell Numbers, Morphology, Cell Cycle Progression and Cell Death in a Tumorigenic and a Non-Tumorigenic Epithelial Breast Cell Line. Journal of Ethnopharmacology, 124, 45-60. http://dx.doi.org/10.1016/j.jep.2009.04.013

[26] Dhar, M.H., Dhar, M.M., Dhawan, B.N., Mahrora, B.N. and Ray, C. (1968) Screening of Indian Plants for Biological Activity: I. Indian Journal of Experimental Biology, 6, 232-247.

[27] Sylvestre, S. and Pandiarajan, K. (2011) NMR Spectral Study of Some2r,6c-Diarylpiperidine-4-One (3'-Hydroxy-2'Napthoyl)Hydrazones with Special Reference to $\gamma$-Syn Effect. Spectrochimica Acta Part A: Molecular and Biomolecular Spectroscopy, 78, 153-159. http://dx.doi.org/10.1016/j.saa.2010.09.015

[28] Gladii, Y.P., Omarov, T.T. and Buranbaev, M.Z. (1993) X-Ray Diffraction Study of 2,4-Diphenyl-9-Ethynyl-3-Azabicyclo-[3.3.1]Nonan-9-Ol. Journal of Structural Chemistry, 34, 336-338. http://dx.doi.org/10.1007/BF00761492

[29] WHO (World Health Organization) (2008) World Cancer Report. 1-26.

[30] Bray, F., Jemal, A., Grey, N., Ferlayand, J. and Forman, D. (2012) Global Cancer Transitions According to the Human Development Index (2008-2030): A Population-Based Study. Lancet Oncology, 13, 790-801. http://dx.doi.org/10.1016/S1470-2045(12)70211-5

[31] Hosono, S., Lee, C.S., Chou, M.J., Yang, C.S. and Shih, C.H. (1999) Molecular Analysis of the p53 Alleles in Primary Hepatocellular Carcinomas and Cell Lines. Oncogene, 6, 237-243.

[32] Le Gall, R., Marchand, C. and Rees, J. (2005) Impacts of Antibiotics on in Vitro UVA-Susceptibility of Human Skin Fibroblasts. European Journal of Dermatology, 15, 146-151.

[33] Xaiver, J.J.F., Krishnasamy, K. and Sankar, C. (2012) Synthesis and Antibacterial, Antifungal Activities of Some 2r,4c-Diaryl-3-Azabicyclo[3.3.1]Nonan-9-One-4-Aminobenzoyl Hydrazones. Medicinal Chemistry Research, 21, 345350. http://dx.doi.org/10.1007/s00044-010-9528-6 